\title{
OBLICZA WSPÓLCZESNEJ LITERATURY UKRAIŃSKIEJ. PRÓBA PODSUMOWANIA
}

\author{
ALBERT NOWACKI \\ Katolicki Uniwersytet Lubelski Jana Pawła II, Lublin — Polska \\ ОБЛИЧЧЯ СУЧАСНОЇ УКРАЇНСЬКОЇ ЛІТЕРАТУРИ. \\ СПРОБА ЗВЕДЕННЯ
}

\begin{abstract}
АЛЬБЕРТ НОВАЦЬКИЙ
Люблінський католицький університет Івана Павла II, Люблін - Польща
\end{abstract}

АНОТАЦІЯ. Стаття є спробою репрезентувати „портрет” сучасної української літератури. Матеріалом для проведення досліджень стали вибрані літературні твори, що побачили світ упродовж останніх двох десятиліть. Проведений аналіз дає змогу зробити висновки про те, що на відстані двадцяти років українська література успішно надолужує втрати, які завдали їй довгі роки комунізму.

\section{THE PORTRAIT OF MODERN UKRAINIAN LITERATURE. AN ATTEMPT OF SUMMARISING}

\section{ALBERT NOWACKI \\ Lublin John Paul II Catholic University, Lublin — Poland}

ABSRACT. The article focuses on the description of modern Ukrainian literature. Literary works published during recent years are the basis of the investigation. The results of the investigation prove the fact of the so-called recovery of literature after a long communist period.

$\mathrm{W}$

roku 2011 nasz wschodni sąsiad - Ukraina - obchodził dwudziestą rocznicę odzyskania niezależności. Jak powszechnie wiadomo, wszelkiego rodzaju jubileusze stanowią znakomite okazje do różnego rodzaju podsumowań i refleksji, zatem wpisując się we wspomniane kanony, postaramy się spojrzeć na kilka aspektów z ukraińskiego życia literackiego, po czym na tej podstawie pokusimy się o przedstawienie portretu współczesnej literatury ukraińskiej.

Większość historyków literatury zgadza się co do tego, że pierwsze wydarzenia zwiastujące nową jakość w literaturze ukraińskiej miały miejsce w drugiej połowie lat 80. ubiegłego wieku. Była to odpowiedź na głęboki kryzys, który już od dłuższego czasu trawił ukraińskie środowiska literackie w związku z daleko posuniętym zinstytucjonalizowaniem oraz koniecznością sprostania wymaganiom polityki partii komunistycznej w dziedzinie literatury. Dla młodszego pokolenia pisarzy stało się jasne, że idea realizmu socjalistycznego jest już ostatecznie skompromitowana, sama zaś literatura powinna zerwać z przeznaczoną dla niej funkcją usłużnej tuby partyjnej i dyżurnego wychowawcy społeczeństwa. Pokolenie, które wypłynęło na fali gorbaczowowskiej pierestrojki i związanej z nią polityki głasnosti niemal od razu zamanifestowało swój kontestacyjny, by nie powiedzieć agresywny stosunek do dotychczasowej sowieckiej tradycji literackiej. Swoją uwagę zwrócili przede wszystkim członkowie grupy Bu-Ba-Bu (Jurij Andruchowycz, Wiktor Neborak i Ołeksandr Irwaneć), 
którzy wykorzystując estetykę farsy i burleski postanowili rozprawić się z tkwiącymi zarówno w samej literaturze, jak też i w społeczeństwie ukraińskim, demonami socrealizmu. Ich niewątpliwą zasługą było, jak słusznie zauważył Bogusław Bakuła, podjęcie próby rozbicia piramidy skamieniałych autorytetów mijającej epoki i jednocześnie stworzenia nowych wzorów literackości i nowych modeli odbioru ${ }^{1}$.

Zarówno śmiałe wystapienia bubabistów, jak też i ich naśladowców w postaci grup Łu-Ho-Sad, Czerwona Fura, Nowa Degeneracja, Propała Hramota, uświadomiły społeczeństwu, że oto nadchodzi kres literatury w postaci, jaką obserwowali dotychczas. Jeszcze bardziej uzmysłowił to rok 1991, który narodowi ukraińskiemu przyniósł długo oczekiwaną wolność i, jak się wtedy wydawało, ostateczne uwolnienie się spod kurateli „starszego brata”. Jedną z niezwykle istotnych kwestii u zarania nowoczesnej państwowości ukraińskiej było pytanie o kształt nowego tworu państwowego: czy powinno być otwarte, czy skoncentrowane na sobie, etniczne czy kosmopolityczne, i wreszcie - jaka powinna być nowa kultura i literatura ukraińska. Jak przekonuje Marcin Wojciechowski, dla starszych działaczy niepodległościowych „nowa Ukraina miała być przede wszystkim projektem etnicznym, realizacja prawa narodu do posiadania własnego państwa",2, młodsi przedstawiciele inteligencji ukraińskiej wychodzili natomiast z przekonania, że o tożsamości i sile ich kraju powinna przede wszystkim decydować kultura ${ }^{3}$.

Jednym z pierwszych pisarzy, który zrozumiał rolę literatury w kształtowaniu postsowieckiego społeczeństwa ukraińskiego był z pewnością Jurij Andruchowycz, który na początku lat 90. opublikował swoje dwie pierwsze powieści: Rekreacje i Moscoviadę. Pierwsza z nich opowiada o swoistej pielgrzymce grupki młodych poetów ukraińskich do Czortopola - miasta w którym odbywać się będzie święto Zmartwychwstałego Ducha. Bohaterowie Andruchowycza zaskakuja, albowiem można o nich powiedzieć wszystko, tylko nie to, że stanowią intelektualną elitę swego narodu. Zamiast pozostawania na piedestale, swoim zachowaniem nie odbiegają od przeciętnego obywatela: lubią suto zakrapiane alkoholem imprezy, rozmawiają o seksie i podbojach miłosnych, ślinią się na widok bardziej atrakcyjnych przedstawicielek płci przeciwnej. Podejrzane jest także samo święto, w którym przyjdzie im wziąć udział, albowiem z tekstu pisarza wyłania się ono jako teatralna parodia na ukraińską retorykę patriotyczną. Druga ze wspomnianych książek to opis przygód młodego poety ukraińskiego w stolicy znienawidzonego imperium, w której autor stara się zdjąć maskę z obecnego przez długi czas w świadomości Ukraińców symbolu, jakim była „Moskwa” i próbuje ukazać jej prawdziwe oblicze. W powieści pisarz poddał także dekonstrukcji obraz Ukrainy i jej miejsce w stosunkach z Rosją oświadczając, że wbrew oficjalnej propagandzie, Ukraina nigdy nie była dla swego wschodniego sąsiada równorzędnym partnerem, sami zaś Ukraińcy pomogli w utrwaleniu tego układu, ponieważ są narodem słabym, bezwolnym i dającym się sterować.

Jako że bubabizm, jak przekonuje Niła Zborowśka, rozpoczął się z wyśmiewania psychologizmu i patriotyzmu ${ }^{4}$, w podobnym duchu utrzymane są też i wspomniane powieści Andruchowicza. Autor starał się obnażyć stereotypy panujące w postradzieckiej Ukrainie. Twierdził, że literatura zaangażowana to przeżytek poprzedniej epoki, a większość tworzących naówczas pisarzy straciło legitymację do poucza-

${ }^{1}$ B. Bakuła, Skrzydło Dedala. Szkice, rozmowy o poezji i kulturze ukraińskiej lat 50-90 XX wieku, Poznań 1999, s. 28-29.

${ }^{2}$ M. Wojciechowski, Pomarańczowy majdan, Warszawa 2006, s. 11.

${ }^{3}$ Tamże.

${ }^{4}$ Н. Зборовська, Код украӥнської літератури. Проект психоісторії новітньої украӥнської літератури, Київ 2006, с. 406. 
nia społeczeństwa, ponieważ, chcąc zachować dotychczasowy poziom życia, stali się zakładnikami różnej maści mecenasów, często niezwykle wątpliwych ${ }^{5}$. Wymowną ilustracją jest tutaj fragment Rekreacji, w którym dwaj poeci - Hryćko Sztundera i Jurko Nemyrycz stojąc na drodze i „łapiąc” tzw. „okazję” do Czortopola, poznają doktora Popiela - szwajcarskiego lekarza jadącego swym luksusowym chryslerem-imperialem na to samo święto. W trakcie krótkiej znajomości zdążyli wyżebrać od uprzejmego kierowcy dwie paczki markowych papierosów, kanapki, prezerwatywy, zapytać o możliwość wyrobienia im zaproszenia do Szwajcarii oraz zainkasować dziesięć dolarów za tomik wierszy w rękopisie:

„Гриць Штундера і Юрко Немирич уже майже годину простояли, голосуючи коло дороги на виїзді з Коломиї, але жодне падло не хотіло спинятися й підбирати їх, хоча всі тримали курс на Чортопіль. I от, коли запас прокльонів та сигарет було вичерпано, а перспектива запізнитись на свято наростала, як загроза громадянської війни, з'явився фантастичний „крайслер-імперіал” із закордонними номерами, і приємний, з сивою борідкою, добродій у картатому кепі й сірому дорожньому вбранні, ласкаво пригальмувавши, запросив їх сідати.

(...) - Я є громадянин Швейцарії, доктор медицини Попель, - відрекомендувався дідусь, коли вони рушили (...).

- Штундера, — повідомив Немирич.

- Немирич, - повідомив Штундера.

- Дуже мені приємно їхати з такими славними поетами, — гречно ошелешив доктор Попель. го всім тілом.

— Ви щось чули про нас? - Юрко, що сидів попереду, розвернувся до ньо-

(...) - Тоді дайте щось закурити, бо в нас закінчилися, — висунувся ззаду Гриць.

- То прошу дуже, - i дві пачки винятково смачних сигарет „голуаз”, випірнувши з магнатської кишені пана Попеля й на мить затримавшись у його правій руці, перелетіли до дірявих кишень мандрівних поетів.

(...) - Пане Попель, а ви могли б нам зробити запрошення у Швейцарію? поцікавився Юрко.

- В тому немає великої потреби, — сказав доктор.

- Ви хотіли сказати, „в тому нема великої складності”? - спробував виправити Гриць.

- Нє, я хотів сказати, що вам ліпше їхати до Америки. Я можу вам зробити запрошення до Америки"б.

W sposób prześmiewczy Andruchowycz nawołuje swych rodaków do zerwania z kompleksami, a zwłaszcza z kompleksem niższości wobec „starszego brata” oraz postuluje odejście od literatury funkcyjnej, często opartej o wzorce narodnickie rodem z XIX wieku. Jest to, jego zdaniem, warunek konieczny do tworzenia nowej literatury ukraińskiej, która mogłaby pomóc rodzącemu się na nowo państwu zrzucić jarzmo sowieckie i stać się krajem samodzielnym.

Powieści Andruchowycza wywołały skrajnie ambiwalentne reakcje wśród spoleczeństwa ukraińskiego. Konserwatyści natychmiast oskarżyli go o „szarganie świętości narodowych", a stosowane przez niego wulgaryzmy sprowadziły zarzuty o poniżanie języka ukraińskiego, oburzał też lekceważący stosunek do autorytetów literackich, a także zbyt jaskrawy, zdaniem krytyków, erotyzm. Dyskusja, któ-

\footnotetext{
${ }^{5} \mathrm{O}$ tym zjawisku wspomina także w swojej książce Bogusław Bakuła, zob. 1, 31-32
}

${ }^{6}$ Ю. Андрухо вич, Рекреаиії. Романи, Київ 1997, с. 42-43. 
ra rozgorzała na łamach ówczesnej prasy literackiej, z jednej strony spowodowała, że z błotem zmieszano nie tylko Andruchowycza, lecz także i całą tzw. postawangar$\mathrm{dę}^{7}, \mathrm{z}$ drugiej jednak strony zapewniła mu ona ogromną popularność wśród wcale licznej gromady nieco bardziej postępowych czytelników.

Niewatpliwą zasługą Jurija Andruchowycza było nie tylko zerwanie z dotychczasową tradycją pisarską rodem z estetyki socrealistycznej, lecz także i przemycenie całej masy motywów, które do tej pory podlegały surowej reglamentacji, jak chociażby język ulicy z całą jego „kwiecistością” czy śmiałe motywy erotyczne. Nie mniej szokujące dla publiczności ukraińskiej było pojawienie się Badań terenowych nad ukraińskim seksem Oksany Zabużko, która obnażyła i wyartykułowała liczne kompleksy społeczeństwa ukraińskiego i zasygnalizowała pojawienie się literatury kobiecej na ukraińskiej arenie literackiej. Największą jednakże zasługą obojga autorów było przekroczenie granicy tkwiącej w mentalności społeczeństwa, które przez kilka dziesięcioleci tkwiło w okowach komunizmu. Była to ewidentna zachęta dla kolejnych pisarzy i już niebawem na ukraińskim rynku księgarskim zaczęły pokazywać się nowe nazwiska i nowe utwory, które zdecydowanie zerwały z tradycją literacką poprzedniej epoki.

Idąc za przykładem Zabużko, na ukraińskim rynku księgarskim pojawiło się wiele powieści napisanych przez kobiety i poświęconych zagadnieniom kobiecej seksualności, erotyki, gdzie często pojawiały się pomijane dotąd w literaturze ukraińskiej kwestie kobiecych pragnień, potrzeb, gdzie mówiono o chęci kobiet do samorealizacji. Pojawiły się więc takie pisarki, jak chociażby Switłana Pyrkało, Jewhenija Kononenko, Iryna Karpa, Natałka Śniadanko czy Sofija Andruchowycz, które piszą nie tyle dla kobiet, ile o kobietach. Ich bohaterki to z pozoru zwyczajne kobiety, jednakże w odróżnieniu od ogółu, chcą decydować o sobie same, niezależnie od mężczyzn; jeśli popełniają błędy, obwiniają za nie jedynie siebie. W powyższy schemat doskonale wpisuje się bohaterka Natalki Śniadanko z powieści Kolekcja namiętno$s ́ c i$. Jest nią wychowująca się w tradycyjnej ,galicyjskiej” rodzinie młoda dziewczyna, która wbrew, a może i na przekór rodzicom, dąży do samodzielnej nauki życia. Ciagle pozostaje autentyczna, pragnie, by akceptowano ją wraz ze wszystkimi wadami i zaletami, zwłaszcza na polu kontaktów męsko-damskich. Nie mieści się jej w głowie stereotypowe przekonanie, że można wyrzec się swojej autentyczności, aby tylko zainteresować sobą jakiegoś mężczyznę. Bohaterka opowiada sytuację, w której namówiona przez koleżankę z klasy, wybiera się na „,polowanie na samca”: , (...) Однокласниця провела зі мною довгу виховну бесіду, під час якої я повинна була усвідомити, як треба поводитися з чоловіками, що грамотність далеко не основне в стосунках із чоловіками і що перш ніж скласти собі про когось думку, варто принаймні раз із ним зустрітися, (...) що при зустрічі кожен чоловік може виявитися не таким уже й дебілом (...). Найбільше вразило мене в тодішній нашій розмові глибоке переконання моєї подруги в тому, що жінка, яка хоче сподобатися чоловікові, повинна поводити себе як справжнісінька ідіотка. „Чим дурніша, тим краще. У розумних не закохуються”, — категорично заявила моя подруга, чим мало не підірвала свій авторитет у моїх очах. Ми довго сперечалися, я намагалася переконати іiі, що видавати себе за дурнішу, ніж ти є насправді, — це самоприниження, а вона перекреслювала всі мої складні й логічні аргументи безжальним: „Фігня це все. Основне, щоб клюнув”.

${ }^{7}$ Ю. Мушкетик, Колесо. Кілька думок з приводу сучасного украӥнського поставангарду, [в:] „Літературна Україна”, 1994, № 44, с. 1, 4; В.B akuła, Skrzydło Dedala. Szkice, rozmowy o poezji i kulturze ukraińskiej lat 50-90 XX wieku, Poznań 1999, s. 28-29; N. Śniadanko, Ahatanhel, Wołowiec 2008, s. 87.

${ }^{8}$ Н. Снядан ко, Колекизія пристрастей або пригоди молодої украӥнки, Харків 2008, с. 32-33. 
Autentyzmu poszukuje także Marla z powieści Freud by płakat Iryny Karpy, która, chcąc stać się naprawdę wolna, ucieka przed kochanymi mężczyznami, albowiem każdy z nich stanowi dla niej jakieś ograniczenie. Bohaterka wyznaje: „Nie mogę być z żadnym mężczyzną. Wy wszyscy jesteście zabójcami wolności. A może raczej ja staję się zabójcą wolności, kiedy tylko przysięgnę żyć razem z mężczyzną. Kochani i niekochani, prawdziwi i przez pomyłkę — od was wszystkich po prostu chce się uciekać"9.

O problemach kobiety w zdominowanym przez mężczyzn świecie biznesu wspomina też bohaterka Switłany Pyrkało (Zełena Marharyta) oraz wykreowana przez Śniadanko Lichosława Galiczanko, bohaterka powieści Ahantanhet, która pracując w redakcji gazety jako jedna z nielicznych kobiet zrywa nawet z odwiecznym stereotypem ubioru właściwego kobiecie. Jak powiada, „Niemal zawsze noszę czarne męskie garnitury i białe koszule. Może zdaniem niektórych zbyt demonstracyjnie świadczy to o dziecięcych traumach mojej podświadomości, ale zmieniać z tego powodu mojego stylu nie zamierzam. Poza tym to bardzo wygodny sposób ubierania się dla kogoś, kto wiecznie marznie (...). Męski styl pozwala na znacznie cieplejsze ubieranie się niż kobiecy"

Kobiece bohaterki najnowszej literatury ukraińskiej coraz głośniej upominają się o swoje prawa, których odmawiały im wyznaczniki estetyki socrealistycznej, i choć może nie robią tego w sposób tak spektakularny, jak działaczki grupy „Femen"11, to jednak podważając tradycyjną rolę mężczyzny w społeczeństwie ${ }^{12}$, łamią przy okazji kilka zakazów, w tym tych nałożonych na pozycję kobiety w świecie polityki i kultury, jak również na kobiece potrzeby seksualne.

Cielesność, w tym także kobieca, jak też seksualność i erotyka to kolejne zdobycze najnowszej literatury ukraińskiej. Jak wiadomo, w literaturze radzieckiej nie tylko seks, ale i sama erotyka były tematami ze sfery tabu. Nie dziwi więc, że po zniesieniu reglamentacji cenzorów ukraińska przestrzeń literacka, która w latach 90. ubiegłego wieku zachłysnęła się wolnością, zaczynała wypełniać się tekstami ociekającymi już nawet nie subtelną erotyka, a po prostu seksem w czystej, nawet tej biologicznej, a więc najbardziej „soczystej” postaci. Ten fenomen pomaga wyjaśnić Sołomija Pawłyczko pisząc: „Еротика, поряд з критикою компартії та частковим відкриттям незнаних сторінок національного минулого, сп'яніла авторів новизною. В текстах, особливо чоловічих, з'явився мат. Література переживала ейфорію розправи над словесними табу. Слово з трьох літер звучало як одкровення і вершина свободи"13. W tym kontekście warto byłoby przytoczyć wspomniane już powieści Jurija Andruchowycza, Śniadanko, prowokatorki Karpy, Ołeksandra Uszkałowa czy nareszcie prozę Jurija Pokalczuka, który w swojej twórczości porwał ze wszelkimi konwenansami i ograniczeniami obyczajowymi. Jego zbiór

${ }^{9}$ I. Karpa, Freud by płakał, Wołowiec 2006, s. 285.

${ }^{10}$ N. Śniadanko, Ahatanhel, Wołowiec 2008, s. 87.

${ }^{11}$ Pełna nazwa: Kobiecy Ruch FEMEN (Жіночий рух FEMEN). Jest to ukraińska organizacja feministyczna, która została założona w 2008 roku w Kijowie. Nadrzędnym celem dla tego kobiecego ruchu społecznego jest walka z problemami i patologiami współczesnego społeczeństwa ukraińskiego, takimi jak naruszanie praw i swobód obywatelskich, seks-turystyka, prostytucja, podwyżki cen i inne problemy gospodarcze. Organizacja znana jest ze śmiałych i skandalizujących akcji protestacyjnych, w których udział biorą członkinie organizacji występujące z obnażonymi piersiami. Więcej informacji można znaleźć na oficjalnej stronie internetowej FEMEN-u, [w:] Źródło elektroniczne: http://femen.info.

${ }^{12}$ Н.Зборовська, Код украӥнської літератури. Проект психоісторї̈ новітньої украӥнської літератури, Київ 2006, с. 427-428.

${ }^{13} \mathrm{C}$. Павлич ко, Виклик стереотипам: нові жіночі голоси в сучасній украйнській літератуpi, [w:] ії ж, Фемінізм, упор. В. Агєєва, Київ 2002, с. 183. 
małych form prozatorskich Te, szczo na spodi ${ }^{14} \mathrm{w}$ rzeczywistości próba zaglądnięcia na samo dno ludzkiej duszy i podejrzenia ukrytych w niej treści. To, co odczytał tam autor, przyprawiłoby o szybsze bicie serca niejednego sowieckiego purystę. Okazuje się bowiem, że najbardziej skrywane pragnienia, marzenia i fantazje człowiecze nieuchronnie ciążą w stronę miłości fizycznej. Wychowany na wolnych o seksu i cielesności wzorcach socrealizmu skonsternowany czytelnik odkrywa, że potrzeby seksualne ujawniają się już we wczesnym wieku młodzieńczym (Wertep), że jest możliwe obcowanie płciowe starszych kobiet z nastolatkami, a także że istnieje tak skrzętnie ukrywana w czasach sowieckich miłość, w tym też miłość fizyczna, dwojga ludzi tej samej płci (Błękitne słońce). Odtąd nie tylko Pokalczuk, ale też i inni pisarze będą raczyć czytelnika szczegółami anatomicznymi i szczegółowo opisywać stosunek płciowy od strony „technicznej”, używając nie tylko leksyki z zakresu medycyny, lecz także wziętej żywcem z sypialni czy podwórka. Czytelnik coraz częściej otrzymuje możliwość podglądania bohaterów w ich czynnościach intymnych, dotychczas szczelnie skrywanych pod ciężką kołdrą i za szczelnie zamkniętymi drzwiami sypialni. Za przykład weźmy chociażby moment przebudzenia się ze snu dwójki bohaterów wykreowanych przez Karpę: ,- Chodźmy na dół. Śniadanie już czeka. A może chcesz, żebym na śniadanie zjadł ciebie? — Hjalmar przeciagnnął ustami po brzuchu Marli. — Jak myślisz: czy seks oralny pomaga pozbyć się bólu głowy? — Nie wiem... — wymruczała Marla — może, na ból głowy nie pomaga, ale świat poprawia na pewno.- Mądra odpowiedź"15.

Motywy seksualne towarzyszą większości skierowanych do młodzieży książek pisanych przez młodsze pokolenie pisarzy. Łatwo je znaleźć u Lubka Deresza ${ }^{16}$, Ołeksandra Uszkałowa ${ }^{17}$, Natalki Śniadanko czy Jewheniji Kononenko ${ }^{18}$. Wydaje się, że jest to z jednej strony wyraz buntu młodego pokolenia pisarzy nie tylko wobec estetyki socrealizmu, lecz także wciąż żywej u progu XXI wieku estetyki wypływającej z tzw. ,ideologii narodnickiej”, w której, jak podkreśla Iryna Betko, pojęcie cielesności było marginalizowane na wszelkie możliwe sposoby ${ }^{19}$. Z drugiej strony coraz bardziej zauważalna obecność erotyki w literaturze jest także wyrazem dojrzewania tejże literatury, owocem podjęcia przez nią twórczych poszukiwań przerwanych w latach 20. ubiegłego wieku i świadczy o ciążeniu ku literaturze Zachodu, która nie stroni przecież od szeroko wymiarowej erotyki.

Istotną wartością współczesnej literatury ukraińskiej jest fakt, że tworzący ją pisarze nie angażują się w otaczającą ich rzeczywistość, lecz się od niej dystansują lub też usiłują podejść do niej z pewną dozą ironii. Taką postawę prezentuje Lichosława Galiczanko wyśmiewająca stereotypy, w których tkwią Ukraińcy z zachodu kraju, z ich separatyzmem galicyjskim na czele. Wykreowana przez Irenę Karpę Marla zauważa natomiast, że jej uwikłani w hołdowanie tradycji rodacy wciąż mentalnie pozostają zaściankowymi Chachłami stłoczonymi na kijowskim Majdanie Niezamożności (gra słów z Majdanem Niezależności) ${ }^{20}$, a ojczyzna jawi się nieatrakcyjną w porównaniu z krajami zachodnioeuropejskimi: „Kiedy Marla wsiadła do pociagu Paryż-Frankfurt i przespała na siedząco jakieś trzy godziny, nie bez podziwu spostrzegła, że: Tęsknota za ojczyzna wyparowała bez śladu. I wątpię, by kiedykolwiek wróciła..."

${ }^{14}$ Ю. Покальчук, Те, щзо на сподi, Львів 1998.

${ }^{15}$ I. Karpa..., s. 38.

${ }^{16}$ A. Nowacki, Aspekty cielesności w prozie Lubka Deresza, [w:] Wielkie tematy kultury w literaturach słowiańskich, t. 9: Ciało, Wrocław 2011, s. 663-670.

${ }^{17}$ О. Ушкалов, БЖД, Київ 2007.

${ }^{18}$ Є. Кононен ко, Без мужика, Львів 2005.

19 I. Бетко, На иляхах духовної інтеграції. Глибиннопсихологічні, релігійно-філософські та ритуально-міфологічні мотиви в украӥнській постмодерній прозі, Olsztyn 2010, с. 97.

${ }^{20}$ I. Karpa..., s. 93. 
Obojętnie kontemplując geranium neurotycznie porozsadzane pod czerwonymi dachami niemieckich burgerów, slajd za slajdem, jakby tasowała talię kart, przerzucała w głowie obrazki z Kijowa. Właśnie tu, w oknach pociagu, mrugał do niej błyskawicznie park Szewczenki z impotentami grającymi w szachy i z zapachem poszukiwań piwa, pseudochińska knajpka $\mathrm{z}$ włosami w zupie, żółtoszare metro, modne sklepy z jednakowymi szmatami, jakieś kawałki armatury i purpurowego marmuru. Pojawili się też ludzie. Wystawali w ciemnych szczerbach drzwi niewielkich pustych stacji i Marla nie mogła ustalić, czy aby na pewno byli to prawdziwi ludzie, czy, jak w większości wypadków, tylko dwuwymiarowe szablony z kartonu. Prawdę ukazywał tylko przekrój’"21.

Podobne nastroje, w których przebija już to żal za „dobrymi” czasami, już to pogarda zaściankowej rzeczywistości, odnajdujemy także w twórczości Serhija Żadana ${ }^{22}$, Jewheniji Kononenko, czy Natalki Śniadanko.

Powyższy cytat z Iryny Karpy przywodzi na myśl jeszcze jedną zdobycz literatury ukraińskiej, którą niewątpliwie należy zaliczyć in plus, a mianowicie coraz częściej pojawiające się opisy innych krajów. Stało się to możliwe dopiero po odzyskaniu przez Ukrainę niepodległości i otwarciu granic. Młodzi ludzie, otrzymali ograniczoną tylko sumą posiadanej gotówki możliwość przemieszczania się nie tylko w obrębie Europy, ale także i całego świata. Z nowych udogodnień skwapliwie skorzystało liczne grono młodych pisarzy ukraińskich, którzy wyjeżdżali w odwiedziny do znajomych, na stypendia, czy też po prostu w poszukiwaniu dodatkowego zarob$\mathrm{ku}$. Zdobyte $\mathrm{w}$ ten sposób doświadczenia przelewali potem na papier. W rezultacie ukraiński czytelnik mógł zapoznać się z realiami życia poza granicami własnego kraju z pierwszej ręki, nie zaś z niepewnych źródeł. Najczęściej opisywanym krajem są tu oczywiście Niemcy, które pojawiają się u Żadana, Śniadanko czy w esejach Andruchowycza, ale też i Polska (Andruchowycz, Śniadanko), Ameryka (Zabużko), a nawet egzotyczne Indie, Tajlandia i Buthan (Karpa).

$\mathrm{Na}$ zakończenie raz jeszcze zapytajmy, jaka jest więc współczesna literatura ukraińska i jak daje sobie radę $\mathrm{w}$ nowej rzeczywistości? Odpowiedź na tak postawione pytanie nie jest prosta. Przede wszystkim musimy zdać sobie sprawę z tego, że zmieniła się funkcja samej literatury. Jak zauważył Jarosław Poliszczuk, na przełomie lat 80. i 90. przeżyła ona szok wraz z całym kanonem literatury socrealistycznej, a na przestrzeni następnego dziesięciolecia poszukiwała nowych inspiracji estetycznych $^{23}$. Obecnie dość łatwo możemy zaobserwować nową jakość nie tylko w samych tekstach literackich, ale też, co podkreśla badacz, w nowym modelu relacji autora z czytelnikiem. Wcześniej zadaniem pisarza była agitacja i edukacja czytelnika, zachęcenie go do większego wysiłku przy budowie kraju, teraz autor zachęca czytelnika do wgłębienia się w tekst, do zabawy tekstem i - za jego pośrednictwem - gry z samym autorem ${ }^{24}$. Dzięki swobodzie poszukiwań twórczych i większej otwartości społeczeństwa ukraińskiego na kulturę Zachodu, młodzi pisarze poszukują nowych środków wyrazu artystycznego i nowych tematów. Pojawiły się zakazane wcześniej seks i erotyka, problem narkotyków i narkomanii, wydarzenia z tragicznej historii narodu ukraińskiego, pojawiła się także długo oczekiwana proza kobieca i literatura genderowa. To wszystko w połączeniu z otwartością na świat, wrażliwością na otaczającą rzeczywistość i gotowością do dalszych poszukiwań i przekraczania granic świadczy, że najnowsza literatura jest na najlepszej drodze do tego, by znów być uważaną za pełnoprawną część nie tylko europejskiego, ale i światowego procesu kulturowego nie tylko przez badaczy literatury, lecz także, a może przede wszystkim, przez coraz liczniejsze grono czytelników.

\footnotetext{
${ }^{21}$ Tamże, s. 7.

${ }^{22}$ S. Żadan, Anarchy in the UKR, Wołowiec 2007; S. Żadan, Big mac, Wołowiec 2005.

${ }^{23}$ Я. Поліщук, Література як геокультурний проект, Київ 2008, с. 285.

${ }^{24}$ Tamże.
} 